\title{
Pro-inflammatory cytokines increase glucose, alanine and triacylglycerol utilization but inhibit insulin secretion in a clonal pancreatic $\beta$-cell line
}

\author{
Aoife Kiely, Neville H McClenaghan ${ }^{\mathbf{1}}$, Peter R Flatt ${ }^{1}$ and Philip Newsholme \\ School of Biomolecular and Biomedical Sciences, Conway Institute, University College Dublin, Belfield, Dublin 4, Ireland \\ ${ }^{1}$ School of Biomedical Sciences, University of Ulster, Coleraine, Northern Ireland \\ (Correspondence should be addresses to P Newsholme; Email: philip.newsholme@ucd.ie)
}

\begin{abstract}
We have investigated the effects of prolonged exposure (24 h) to pro-inflammatory cytokines on $\beta$-cell metabolism and insulin secretion using clonal BRIN-BD11 $\beta$ cells. Addition of IL- $1 \beta$, tumour necrosis factor- $\alpha$ and IFN- $\gamma$ (at concentrations that did not induce apoptosis) inhibited chronic $(24 \mathrm{~h})$ and acute stimulated levels of insulin release (by 59 and 93\% respectively), increased cellular glucose and alanine consumption, and also elevated lactate and glutamate release.
\end{abstract}

However, ATP levels and cellular triacylglycerol were decreased while glutathione was increased. We conclude that sub-lethal concentrations of pro-inflammatory cytokines appear to shift $\beta$-cell metabolism away from a key role in energy generation and stimulus-secretion coupling and towards a catabolic state which may be related to cell defence. Journal of Endocrinology (2007) 195, 113-123

\section{Introduction}

Nutrient metabolism is tightly coupled to insulin secretion in the pancreatic $\beta$ cell (McClenaghan 2007). Mitochondrial metabolism is crucial for the coupling of glucose and amino acid recognition to exocytosis of insulin granules. This is illustrated by in vitro and in vivo observations that mitochondrial dysfunction severely impairs insulin secretion. Mitochondria generate ATP which, in addition to $\mathrm{Ca}^{2+}$, is the main coupling messenger in insulin secretion. Mitochondria generate additional coupling factors, which serve as sensors for the control of the exocytotic process (Wollheim 2000, Maechler 2002). Numerous studies have sought to identify the factors that mediate the key amplifying pathway over the $\mathrm{Ca}^{2+}$ signal in nutrient-stimulated insulin secretion. Predominantly, these factors are nucleotides (ATP, GTP, cAMP and NADPH), although metabolites have also been proposed, such as long-chain acyl-CoA derivatives and glutamate (Maechler \& Wollheim 1999). Glucose, alanine and glutamine metabolism in the $\beta$ cell may generate many, if not all, of the mitochondrial factors described above (Brennan et al. 2002, 2003, Dixon et al. 2003, Newsholme et al. 2003, Corless et al. 2006). Glucose has been reported to protect $\beta$ cells from apoptosis (Hoorens et al. 1996), while glutamine has been reported to afford protection from apoptosis in a wide variety of cells (Curi et al. 2005).

We have previously presented ${ }^{13} \mathrm{C}$ NMR data which provided novel evidence for substantial intracellular pancreatic $\beta$-cell metabolism of $\mathrm{L}$-glutamine resulting in the formation of L-glutamate, L-aspartate and glutathione (GSH; Brennan et al. 2003). We proposed that L-glutamate production is important to the $\beta$ cell as an intermediate of the $\gamma$-glutamyl cycle, which regulates cellular GSH concentration. We have also reported that $\mathrm{L}$-alanine or L-glutamine can chronically regulate gene expression in the clonal $\beta$-cell line BRIN-BD11 (Cunningham et al. 2005, Corless et al. 2006). Differentially regulated genes included the antioxidant enzyme catalase and the key regulatory fatty acid synthesis enzyme acetyl-CoA carboxylase (ACC). As both the cell redox status and acyl-CoA derivatives are important for optimal regulation of insulin secretion, chronic amino acid exposure may alter chronic levels of insulin secretion.

Glucose-stimulated insulin secretion was reduced after exposure to the pro-inflammatory cytokines IL-1 $\beta$, tumour necrosis factor- $\alpha$ (TNF- $\alpha$ ) and IFN- $\gamma$ in human, mouse and rat islets (Cunningham \& Green 1994). Primary pancreatic islets from rats or mice demonstrated reduced glucose oxidation and pyruvate dehydrogenase (PDH) activity after incubation in relatively high concentrations of IL-1 $\beta$ or TNF- $\alpha$ respectively (Eizirik et al. 1988, Park et al. 1999). High concentrations of pro-inflammatory cytokines (IL-1 $\beta$, TNF- $\alpha$ and IFN- $\gamma$ ) are also known to increase apoptosis in both pancreatic $\beta$-cell lines and primary islet cells (Rabinovitch et al. 1996). The mechanism by which these proinflammatory cytokines induce $\beta$-cell apoptosis may be partially dependent on increased inducible nitric oxide 
synthase (iNOS) expression and nitric oxide (NO) generation. In a recent paper, it was reported that $46 \%$ of the genes modified by cytokines after 8-24 h exposure were NO dependent (Kutlu et al. 2003), but inhibition of NO production did not protect INS-1E cells from apoptosis. Similarly in iNOS knockout mice, the rate of apoptosis in primary islets was delayed but not prevented (Liu et al. 2000).

Reactive oxygen species (ROS) may contribute to $\beta$-cell dysfunction and apoptosis. The source of ROS may be mitochondrial or the plasma membrane associated NADPH oxidase. Expression of a functional NADPH oxidase in islet cells was recently reported, as was up-regulation by IL- $1 \beta$ or a cocktail of IL-1 $\beta$, TNF- $\alpha$ and IFN- $\gamma$ (Oliveira et al. 2003, Morgan et al. 2007). Up-regulation of $\mathrm{O}_{2}^{-}$generation in the $\beta$ cell may lead to ROS-dependent damage and also peroxynitrite formation (following the reaction of $\mathrm{O}_{2}^{-}$with $\mathrm{NO}$ ) resulting in subsequent induction of apoptosis. The generation of $\mathrm{NO}$ and ROS requires metabolic input, firstly to provide L-arginine, a substrate for NO synthesis, and secondly to provide NADPH, required for both $\mathrm{NO}$ and ROS production from iNOS and NADPH oxidase respectively. Indeed, the largest cluster of genes altered on addition of IL$1 \beta$ and IFN $\gamma$ in primary rat $\beta$ cells was associated with metabolism (Cardozo et al. 2001).

We hypothesized that exposure of $\beta$ cells to low, non-lethal concentrations of cytokines would initiate a change in metabolism that would favour cell defence at the expense of insulin secretion. Indeed, we now report that chronic $(24 \mathrm{~h})$ exposure of clonal BRIN-BD11 $\beta$ cells to sub-lethal concentrations of IL- $1 \beta$, TNF- $\alpha$ and IFN- $\gamma$ inhibited chronic and acute levels of insulin secretion (by 59 and $93 \%$ respectively) but induced significant increases in glucose, alanine and triacylglycerol utilization and glutamate release. The clonal $\beta$-cell line BRIN-BD11 was chosen for this work as metabolic, signalling, insulin secretory and cell viability responses to glucose, amino acids as well as other stimuli have been well characterized (McClenaghan et al. 1996a, Chapman et al. 1999, McClenaghan \& Flatt 1999, Brennan et al. 2002, 2003).

\section{Materials and Methods}

\section{Culture of BRIN-BD11 pancreatic $\beta$ cells}

Clonal insulin-secreting BRIN-BD11 cells were maintained in RPMI-1640 tissue culture medium supplemented with $10 \%(\mathrm{v} / \mathrm{v})$ fetal calf serum (FCS), $0 \cdot 1 \%$ antibiotics $(100 \mathrm{U} / \mathrm{ml}$ penicillin and $0 \cdot 1 \mathrm{mg} / \mathrm{ml}$ streptomycin) and $11 \cdot 1 \mathrm{mmol} / 1 \mathrm{D}-$ glucose, $\mathrm{pH} 7 \cdot 4$. The origin of BRIN-BD11 cells are described elsewhere (McClenaghan et al. 1996a,b). These cells provide an appropriate $\beta$-cell model as evidenced by studies of insulin secretion (McClenaghan et al. 1996a,b, McClenaghan \& Flatt 1999), $\beta$-cell metabolism (Brennan et al. 2002, 2003, McClenaghan 2007), electrophysiology (Chapman et al. 1999), $\mathrm{Ca}^{2+}$ handling (Van Eylen et al. 2002) and cellular defence (Conroy et al. 2002).
The cells were maintained at $37{ }^{\circ} \mathrm{C}$ in a humidified atmosphere of $5 \% \mathrm{CO}_{2}$ and $95 \%$ air using a Forma Scientific incubator (Marietta, OH, USA). The cells were cultured in 50-70 ml RPMI-1640 tissue culture medium in T175 sterile tissue culture flasks. Cells were subsequently seeded into six-well plates $\left(1.5 \times 10^{6}\right.$ cells per well $)$ and allowed to adhere overnight. Cells were then washed with PBS after which they were incubated in fresh media, containing $11.1 \mathrm{mM}$ D-glucose, $2 \mathrm{mM}$ L-glutamine or other as described below, in the absence or presence of a pro-inflammatory cytokine cocktail (IL-1 $\beta$ 0.3125 U/ml, TNF $\alpha$ 31.25 U/ml, IFN $\gamma$ $15 \cdot 625 \mathrm{U} / \mathrm{ml}$ ). After $24-\mathrm{h}$ incubation, an aliquot of the media was removed and centrifuged at $200 \mathrm{~g}$ for $5 \mathrm{~min}$ and used for quantitation of insulin and metabolites (D-glucose, L-glutamine, L-alanine, L-glutamate, TAG and GSH).

\section{Enzymatic determination of metabolites}

Glucose The standard glucose concentration in RPMI 1640 medium at the beginning of incubation $(11.1 \mathrm{mmol} / 1$ in the presence of $2 \mathrm{mmol} / \mathrm{l}$ glutamine) and $24 \mathrm{~h}$ after culture was determined using a commercially available kit (Sigma). The glucose utilized over the 24-h period was calculated by subtracting the concentration at $24 \mathrm{~h}$ from that at $0 \mathrm{~h}$.

L-Alanine The alanine concentration at the beginning of incubation $(10 \mathrm{mmol} / \mathrm{l}$ added to standard RPMI 1640 containing $11.1 \mathrm{mmol} / 1$ glucose and $2 \mathrm{mmol} / 1$ glutamine) and $24 \mathrm{~h}$ after culture was determined by a spectrophotometric assay based on the oxidation of L-alanine to pyruvic acid and ammonia in the presence of $\mathrm{NAD}^{+}$and alanine dehydrogenase. The increase in absorbance at $339 \mathrm{~nm}$ due to formation of NADH was used to quantify the amount of L-alanine consumed (Dixon et al. 2003).

L-Glutamine and L-glutamate The glutamine concentration at the beginning $(2 \mathrm{mmol} / \mathrm{l}$ in the presence of $11.1 \mathrm{mmol} / \mathrm{l}$ glucose) and $24 \mathrm{~h}$ after culture was determined based on its hydrolysis to glutamic acid and ammonium ions $\left(\mathrm{NH}_{4}^{+}\right)$in a reaction catalysed by asparaginase. $\mathrm{NH}_{4}^{+}$generated combined with 2-oxoglutarate in the presence of NADH to form glutamic acid, $\mathrm{NAD}^{+}$and water. The concentration of glutamine in the sample was quantified indirectly by measuring the decrease in absorbance at $340 \mathrm{~nm}$ due to the conversion of $\mathrm{NADH}$ into $\mathrm{NAD}^{+}$. (Dixon et al. 2003). The L-glutamate concentration in the culture media was measured using a glutamate dehydrogenase (GDH)-based diagnostic kit (Roche Diagnostics). The L-glutamine is hydrolysed to L-glutamate spontaneously at $37^{\circ} \mathrm{C}$ at a rate of approximately $5 \% / 24$ h over a concentration range of 1-20 $\mathrm{mM}$. This spontaneous rate of hydrolysis was taken into account when calculating rates of glutamate or $\mathrm{NH}_{4}^{+}$production.

Triacylglycerol (triglyceride) Cellular triacylglycerol content was measured as outlined by Dixon et al. (2003). Following 24-h culture in the presence or absence of the 
cytokine cocktail, cells were washed with PBS, trypsinized and resuspended in $2 \mathrm{mM} \mathrm{NaCl}, 20 \mathrm{mM}$ EDTA, and $50 \mathrm{mM}$ sodium phosphate $(\mathrm{pH} 7 \cdot 4)$ and sonicated for 1-2 min. Homogenate measuring $10 \mu \mathrm{l}$ was mixed with $10 \mu \mathrm{l}$ tert-butyl alcohol and $5 \mu \mathrm{l}$ triton-X-100/methyl alcohol $(1: 1, \mathrm{v} / \mathrm{v})$ for the extraction of the lipids. Triacylglyerol was determined using a commercial kit (Human, Wiesbaden, Germany) and expressed as $\mu \mathrm{g} / \mathrm{mg}$ protein.

Oxidized and total GSH Oxidized glutathione (GSSG) was quantified in a microtitre plate according to the technique of Baker et al. (1990) using the method originally described by Tietze (1969). Cell lysate or GSSG standards $(0-500 \mathrm{pmol}$ of $\mathrm{GS}$ /microlitre) were transferred into a microtitre plate and diluted with water. After addition of reaction mixture $(0 \cdot 1 \mathrm{M}$ sodium phosphate buffer ( $\mathrm{pH} 7 \cdot 5)$ containing $1 \mathrm{mM}$ EDTA, $0.3 \mathrm{mM}$ DTNB, $0.4 \mathrm{mM}$ NADPH and $1 \mathrm{U} / \mathrm{ml} \mathrm{GSH}$ reductase, the increase in absorbance at $405 \mathrm{~nm}$ was detected at 15 -s intervals over a range of $2.5 \mathrm{~min}$ using a microtitre plate reader. GSH contents were evaluated using a calibration curve. Intracellular reduced GSH) was measured using the membrane-permeant monochlorobimane (Kamencic et al. 2000). Monochlorobimane readily enters the cell where it forms a fluorescent GSH-monochlorobimane adduct that can be measured fluorometrically. This reaction is catalysed by intracellular GSH-S-transferase. This method was used to semi-quantitatively measure the increase or decrease in intracellular GSH after treatment with the cytokine cocktail.

ATP ATP was determined using the luciferase assay (Biovision, Cambs, UK). After 24-h incubation in the presence or absence of the cytokine cocktail, cells were lysed and ATP quantified using the luciferase assay and extrapolated from a standard curve.

\section{Protein determination}

Cellular protein was determined using a BCA protein assay kit (Pierce, Rockford, IL, USA kit no. 23225), which utilizes a modification of the biuret reaction.

\section{Western blot analysis}

Using RIPA lysis buffer (Upstate Biochemicals, Lake Placid, NY, USA), $20 \mu \mathrm{g}$ BRIN-BD11 cell protein extracts were prepared. Samples were subsequently subjected to $6 \%$ SDSPAGE and electrophoretically transferred onto a nitrocellulose sheet. The sheet was blocked in 5\% milk protein and incubated with polyclonal anti-ACC, AMPK (Santa Cruz Biotechnology, Santa Cruz, CA, USA) or 3\% BSA and incubated with polyclonal AMPK-P (adenosine 5'-monophosphate activated kinase-phosphorylated). The blots were washed and probed with horseradish peroxidase and visualized with Supersignal West Pico chemiluminescent substrate (Pierce).

\section{RT-PCR}

Total RNA was extracted from BRIN-BD11 cells using TRIzol reagent (Invitrogen) according to the manufacturer's protocol applying 50-100 mg of cell extract per $1 \mathrm{~mL}$ TRIzol reagent. DNase-treated RNA samples were then used as templates for cDNA synthesis using appropriate primers for LDH (forward primer CCGTTACCTGATGGGAGAAA, reverse primer TTATGCTCTCGGCCAAGTCT) or GAPDH as control. The PCR products were resolved on a $1 \%$ agarose gel and the intensity of ethidium bromide staining was quantified using the GeneGenius gel documentation and analysis system. Lactate dehydrogenase (LDH) expression changes were calculated relative to the GAPDH expression as a control.
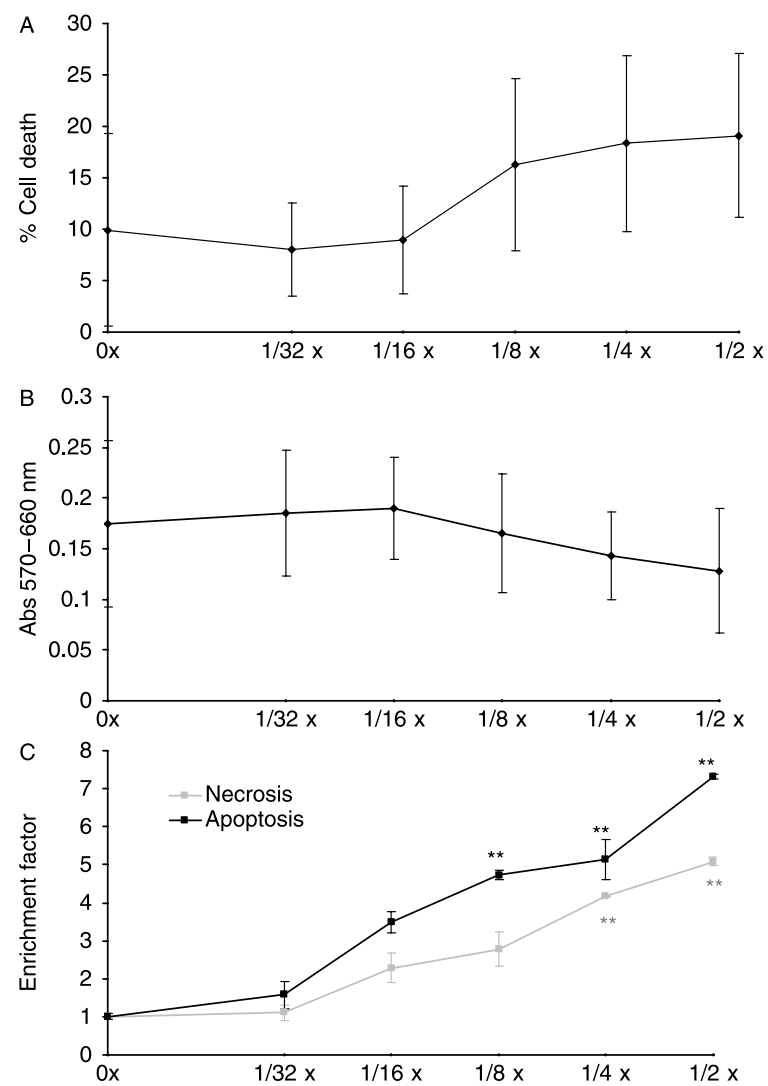

Figure 1 Determination of BRIN-BD11 cellular integrity after 24-h treatment with various concentrations of a pro-inflammatory cytokine cocktail. BRIN-BD11 cells were incubated in RPMI-1640 media supplemented with $10 \%(\mathrm{v} / \mathrm{v}) \mathrm{FCS}$ and $2 \mathrm{mmol} / \mathrm{l}$ glutamine. Cell integrity $(\%)$ was measured by either $\mathrm{LDH}$ release compared with total LDH concentrations (A), determination of mitochondrial viability using the MTT assay (B) or determining the level of apoptosis and necrosis (C) using a DNA fragmentation assay (Roche Diagnostics). Cytokine levels used in cell incubations were dilutions from a stock of concentration; $1 \times=\mathrm{IL}-1 \beta(10 \mathrm{ng} / \mathrm{ml})$, TNF- $\alpha(7 \cdot 5 \mathrm{ng} / \mathrm{ml}), \mathrm{IFN}-\gamma(500 \mathrm{ng} / \mathrm{ml})$, which is equivalent to IL-1 $\beta$ $(5 \mathrm{U} / \mathrm{ml}), \mathrm{TNF}-\alpha(500 \mathrm{U} / \mathrm{ml}), \mathrm{IFN}-\gamma(250 \mathrm{U} / \mathrm{ml})$. Results are expressed as mean \pm s.D. ${ }^{*} P<0 \cdot 05,{ }^{* *} P<0 \cdot 01$. 

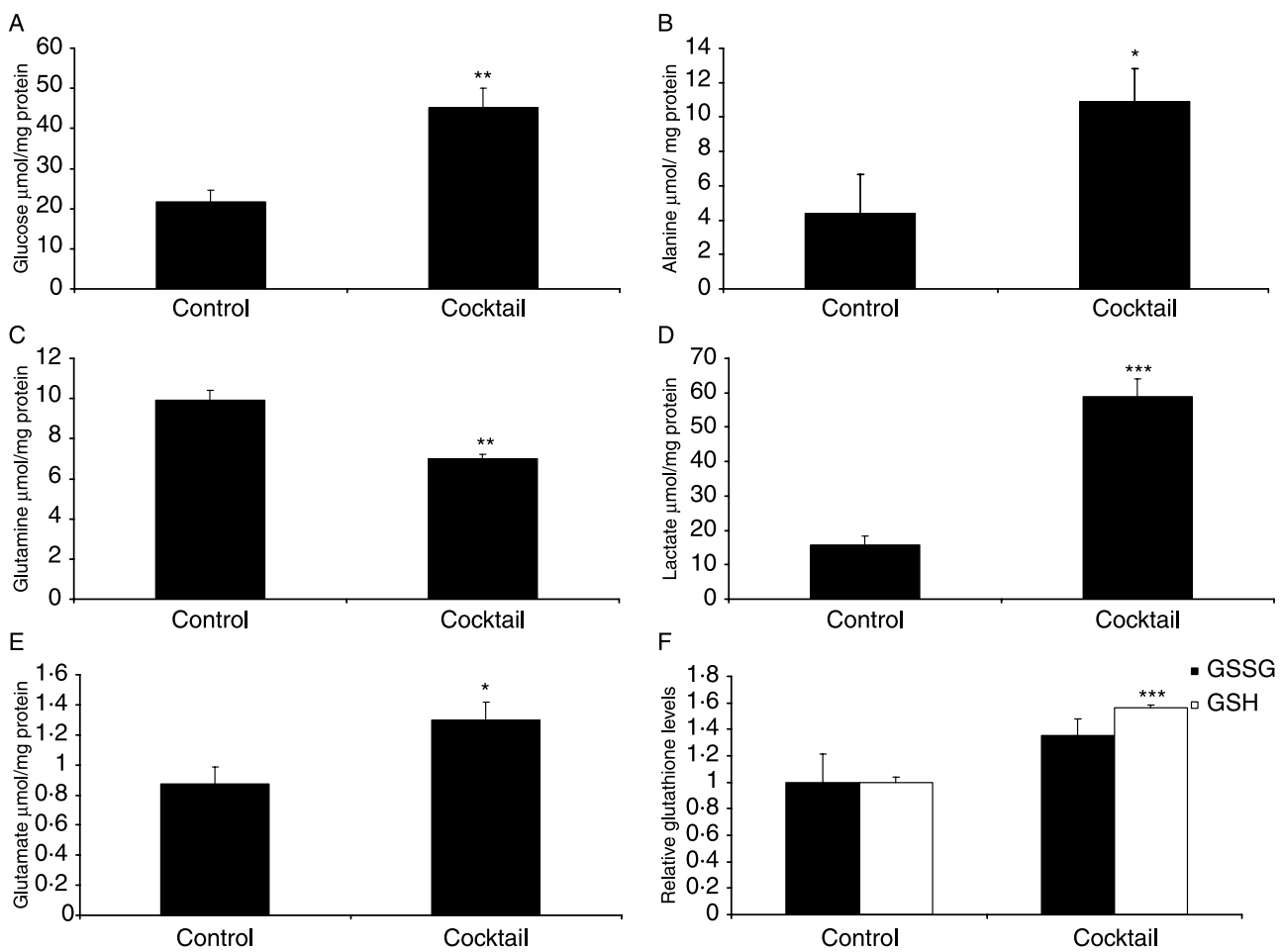

Figure 2 The effect of pro-inflammatory cytokines on glucose, glutamine and alanine consumption and lactate, glutamate and glutathione production in BRIN-BD11 cells. Cells were incubated in RPMI-1640 media supplemented with $10 \%(\mathrm{v} / \mathrm{v}) \mathrm{FCS}$ and $2 \mathrm{mmol} / \mathrm{l}$ glutamine and $10 \mathrm{mmol} / \mathrm{l}$ alanine where indicated. Glucose (A), alanine $(B)$ and glutamine $(C)$ consumption after 24-h treatment of BRIN-BD11 cells with the proinflammatory cytokine cocktail. Lactate $(D)$, glutamate $(E)$ and glutathione $(F)$ production after 24-h treatment of BRIN-BD1 1 cells with the pro-inflammatory cytokine cocktail. Results are $n=6$ in duplicate (A, C-E), $n=3$ in duplicate (B), $n=3(\mathrm{~F}) .{ }^{*} P<0 \cdot 05,{ }^{* *} P<0 \cdot 01,{ }^{* * *} P<0 \cdot 001$.

\section{Chronic (24 h) and acute levels of insulin secretion}

BRIN-BD11 cells were seeded in 24 -well plates $\left(1 \times 10^{5}\right.$ cells/well) in RPMI-1640 medium containing $11 \cdot 1 \mathrm{mM}$ D-glucose in the absence or presence of the cytokine cocktail (IL-1 $\beta \quad 0.3125 \mathrm{U} / \mathrm{ml}, \quad$ TNF $\alpha \quad 31 \cdot 25 \mathrm{U} / \mathrm{ml}, \quad$ IFN $\gamma$
$15 \cdot 625 \mathrm{U} / \mathrm{ml})$. After 24-h incubation, an aliquot of the media was removed and centrifuged at $200 \mathrm{~g}$ for $5 \mathrm{~min}$ and analysed for insulin content using the Mercodia Ultrasenstive Rat Insulin ELISA kit (Uppsala, Sweden). Additionally, some cells were further incubated for $40 \mathrm{~min}$ in the presence of $1.1 \mathrm{mmol} / 1$ glucose followed by $20 \mathrm{~min}$ in the presence of $16.7 \mathrm{mM}$ glucose

A
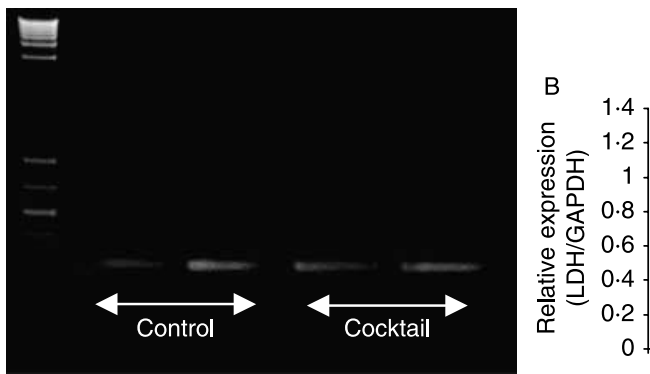

$\left.\begin{array}{l}4 \\ 2 \\ 8 \\ 6 \\ 4 \\ 2 \\ 0\end{array}\right]$

Figure 3 The effect of pro-inflammatory cytokines on BRIN-BD11 $\beta$-cell lactate dehydrogenase expression. RT-PCR analysis of LDH expression levels in BRIN-BD11 cells incubated for $24 \mathrm{~h}$ in the absence or presence of the pro-inflammatory cytokine cocktail. RNA extraction and analysis was as described in the Materials and Methods section. The PCR products were resolved on a $1 \%$ agarose gel (A) and the intensity of ethidium bromide staining was quantified using the GeneGenius gel documentation and analysis system before displaying relative to GAPDH (B). 
and $10 \mathrm{mM}$ alanine (a stimulus that results in a robust and reproducible secretory response in normal conditions, McClenaghan et al. 1996a,b, Brennan et al. 2002), when an aliquot of the incubation medium was removed, centrifuged at $200 \mathrm{~g}$ for $5 \mathrm{~min}$ and analysed for insulin using the Mercodia Ultrasenstive Rat Insulin ELISA kit. The insulin content of cells was not significantly different in any of the incubation conditions described in this paper.

\section{Statistical analysis}

The results are presented as mean \pm s.D. Groups of data were compared using a Student's unpaired $t$-test or ANOVA where appropriate. Differences were considered significant at a $P$ value of $<0 \cdot 05$.

\section{Results}

Pro-inflammatory cytokine-induced changes in cellular integrity

Cell integrity was investigated by use of three different methods. LDH release can be determined after loss of plasma membrane integrity. This assay demonstrated that there was no significant change in \% cell death after 24-h treatment with the pro-inflammatory cytokine cocktail up to and including a concentration of $1 / 16 \times$ $(1 \times$ consisted of $\mathrm{IL}-1 \beta 5 \mathrm{U} / \mathrm{ml}, \mathrm{TNF} \alpha 500 \mathrm{U} / \mathrm{ml}$, IFN $\gamma 250 \mathrm{U} / \mathrm{ml})$. At $1 / 8 \times$ there was an increase from $9 \cdot 9 \pm 4 \cdot 7$ to $16 \cdot 3 \pm 4 \cdot 2 \% \quad P=0 \cdot 057$. At higher concentrations of $1 / 4 \times$ and $1 / 2 \times$, there were further losses in cellular plasma membrane integrity (Fig. 1A). Examination of mitochondrial viability using the MTT assay demonstrated that there was no significant change in activity after treatment with the pro-inflammatory cytokine cocktail up to and including $1 / 2 \times$ (with respect to IL-1 $\beta 5 \mathrm{U} / \mathrm{ml}$, TNF $\alpha 500 \mathrm{U} / \mathrm{ml}$, IFN $\gamma$ $250 \mathrm{U} / \mathrm{ml})$. This result would indicate that BRINBD11 cell mitochondria are relatively resistant to cytokine-induced damage.

Assessment of apoptotic cell death by determination of DNA fragmentation, based on an ELISA, demonstrated that there was no significant change in apoptotic cell death after 24-h treatment with the pro-inflammatory cytokine cocktail, up to and including $1 / 16 \times$ (where $1 \times=\mathrm{IL}-1 \beta 5 \mathrm{U} / \mathrm{ml}$, TNF $\alpha 500 \mathrm{U} / \mathrm{ml}$, IFN $\gamma 250 \mathrm{U} / \mathrm{ml})$. A fourfold increase in fragmentation was seen after treatment with $1 / 8 \times$ which further increased to a sevenfold increase after treatment with $1 / 2 \times$ (Fig. 1C). Examination of necrotic cell death using the DNA ELISA revealed that there was no significant increase in necrotic death until a cocktail concentration of $1 / 4 \times$ was used, which resulted in a fourfold increase in necrosis which further increased to a fivefold increase after treatment with a concentration of $1 / 2 \times$ (Fig. 1C).
Pro-inflammatory cytokine induced-changes in glucose, alanine and glutamine consumption

The concentration of the cytokine cocktail chosen for further experiments was $1 / 16 \times$ (corresponding to final incubation concentrations of IL-1 $\beta 0 \cdot 3125 \mathrm{U} / \mathrm{ml}, \mathrm{TNF} \alpha 31 \cdot 25 \mathrm{U} / \mathrm{ml}$ and IFN $\gamma 15 \cdot 625 \mathrm{U} / \mathrm{ml}$ ) as this concentration did not result in significant changes in cellular integrity. There was a twofold significant increase in glucose consumption after treatment with the pro-inflammatory cytokine cocktail $(20 \cdot 47 \pm 5 \cdot 31$ to $44 \cdot 61 \pm 6 \cdot 67 \mu \mathrm{mol}$ glucose $/ \mathrm{mg}$ protein/24 h, $P<0 \cdot 001$; Fig. 2A).

Alanine consumption was also significantly increased after treatment with the pro-inflammatory cytokine cocktail $(4 \cdot 38 \pm 2 \cdot 31$ to $10 \cdot 92 \pm 1 \cdot 90 \mu \mathrm{mol}$ alanine $/ \mathrm{mg}$ protein $/ 24 \mathrm{~h}$, $P<0 \cdot 01)$, corresponding to a $150 \%$ increase in alanine consumption over the $24-\mathrm{h}$ period (Fig. 2B). In contrast,
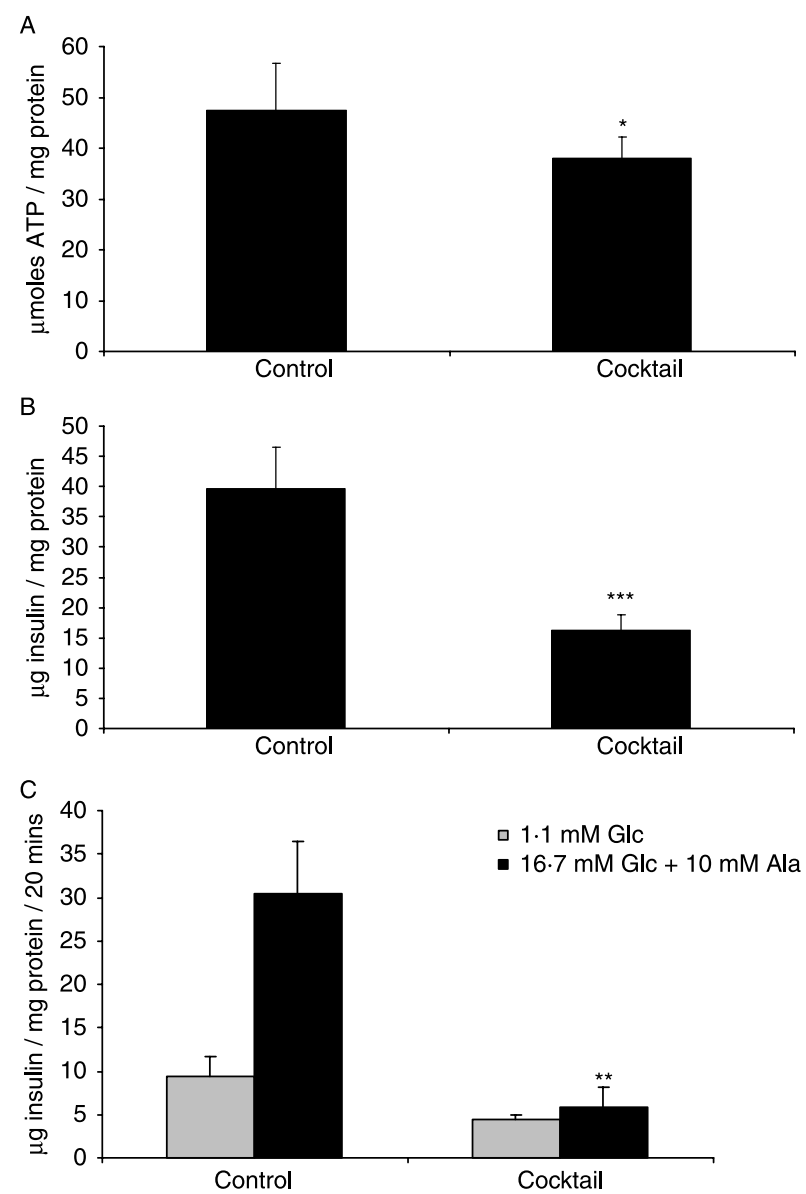

Figure 4 The effect of pro-inflammatory cytokines on ATP levels and insulin secretion in BRIN-BD11 cells. Exposure to a proinflammatory cytokine cocktail for $24 \mathrm{~h}$ changed intracellular ATP concentration (A), chronic levels of insulin secretion (B) and acute stimulation of insulin secretion using a stimulus of $16.7 \mathrm{mM}$ glucose plus $10 \mathrm{mM}$ alanine (C) from BRIN-BD11 cells. Results are expressed as mean \pm s.D. ${ }^{*} P<0 \cdot 05,{ }^{* *} P<01, * * * P<0 \cdot 001$ compared with incubation in the absence of cytokines. 


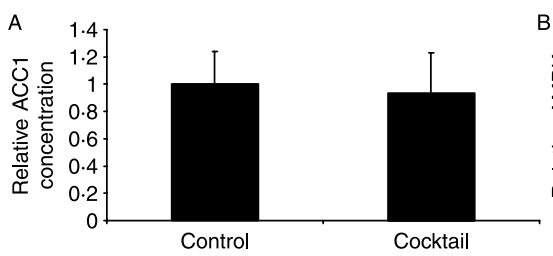

D

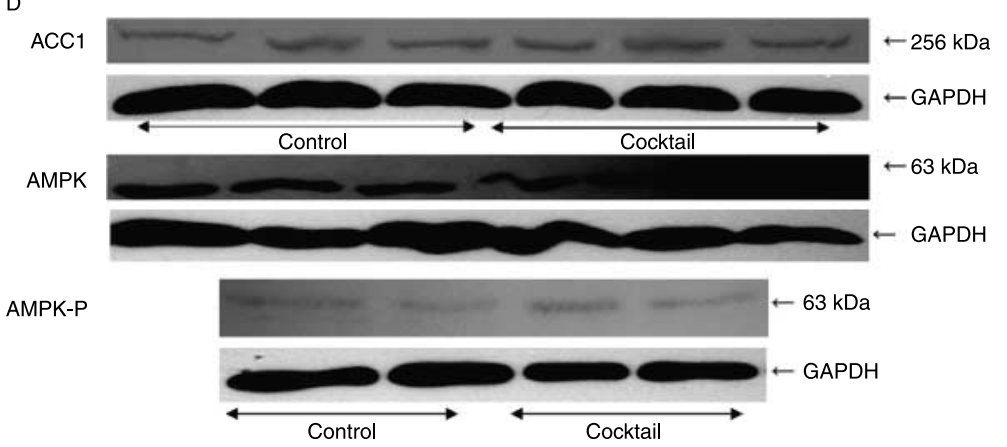

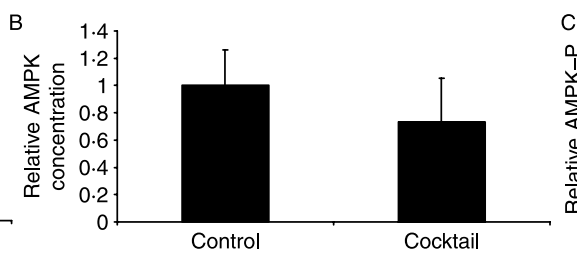

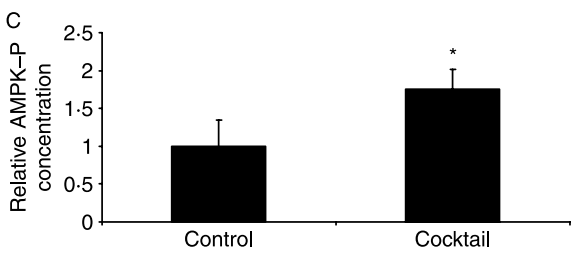

E

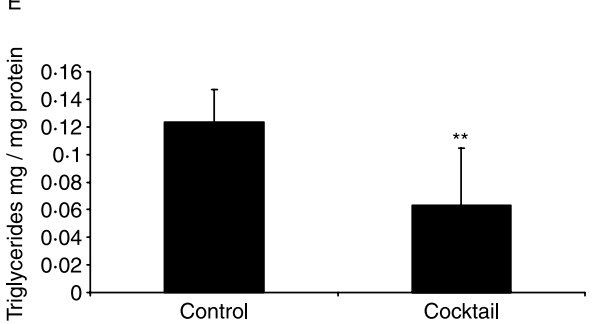

Figure 5 The effect of pro-inflammatory cytokines on ACC, AMPK and intracellular triacylglycerol levels in BRIN-BD11 cells. Protein expression of ACC1, AMPK and phosphorylated AMPK in BRIN-BD11 cells were determined by western blot analysis (Panels A, B, C respectively) after 24-h treatment with the pro-inflammatory cytokine cocktail. Results are expressed as mean \pm s.D. using GAPDH as an expression control (Panel D) $* P<0 \cdot 05$. Intracellular triglyceride concentration of BRIN-BD11 cells after 24-h treatment with the proinflammatory cytokine cocktail (Panel E). Results are expressed as mean \pm s.D. for $n=3$ in duplicate. ${ }^{* *} P<0 \cdot 01$.

glutamine consumption was significantly decreased by the pro-inflammatory cytokine cocktail $(9.90 \pm 0.49$ to $7 \cdot 00 \pm 0 \cdot 21 \mu \mathrm{mol}$ glutamine $/ \mathrm{mg}$ protein $/ 24 \mathrm{~h}, \quad P<0 \cdot 01)$, corresponding to a $29 \%$ reduction in glutamine consumption over the 24-h period (Fig. 2C).

Pro-inflammatory cytokine-induced changes in lactate, glutamate and GSH production

A $271 \%$ increase in lactate production was observed after treatment with the pro-inflammatory cytokine cocktail. After 24-h incubation, lactate production had increased from $15 \cdot 87 \pm 6 \cdot 09$ to $58 \cdot 81 \pm 13 \cdot 11 \mu \mathrm{mol}$ lactate/mg protein, $P<0.001$ (Fig. 2D). LDH expression and activity were determined after $24-\mathrm{h}$ incubation in the absence or presence of the pro-inflammatory cytokine cocktail. The LDH expression was not altered after exposure to the proinflammatory cytokine cocktail (Fig. 3A and B) and neither was $V_{\max }$ activity determined via kinetic plot ( $V_{\max }$ after incubation in the absence or presence of the pro-inflammatory cytokines for $24 \mathrm{~h}$ was $453 \pm 52$ or $579 \pm 124 \mathrm{nmol} / \mathrm{mg}$ protein/min respectively). Glutamate release significantly increased from $0 \cdot 87 \pm 0 \cdot 28$ to $1 \cdot 30 \pm 0 \cdot 28 \mu \mathrm{mol}$ glutamate/ mg protein after $24 \mathrm{~h}$, a $49 \%$ increase in glutamate release, $P<0.05$ (Fig. 2E). Intracellular levels of reduced $\mathrm{GSH}$, significantly increased by $1 \cdot 6$-fold after $24 \mathrm{~h}, P<0 \cdot 001$ (Fig. 2F). Similarly intracellular levels of GSSG, were increased by $1 \cdot 4$-fold after treatment with the pro-inflammatory cytokine cocktail for $24 \mathrm{~h}, P=0 \cdot 07$.
Pro-inflammatory cytokine-induced changes in ATP concentration and insulin secretion

ATP concentration was determined by luciferase assay after treatment for $24 \mathrm{~h}$ in the presence of various concentrations of the pro-inflammatory cytokine cocktail. There was a $20 \%$ reduction in intracellular ATP concentration (from $47.56 \pm$ $9 \cdot 20$ to $38 \cdot 04 \pm 4 \cdot 14$ pmol ATP per $\mathrm{mg}$ protein, $P<0 \cdot 01$, Fig. 4A). The fall in ATP content after $24 \mathrm{~h}$ may reflect increased rates of consumption of ATP relative to generation.

A $59 \%$ reduction in chronic insulin secretion was observed after 24-h treatment of BRIN-BD11 cells with the proinflammatory cytokine cocktail. Total insulin secreted over the 24-h period was reduced from $39 \pm 7$ to $16 \pm 3 \mu \mathrm{g}$ insulin/mg protein $/ 24$ h, $P<0.001$ (Fig. 4B). A more dramatic inhibition of an acute $(40 \mathrm{~min})$ nutrient stimulus $(16.7 \mathrm{mM}$ glucose plus $10 \mathrm{mM}$ alanine) of insulin secretion was observed after 24-h treatment of BRIN-BD11 cells with the pro-inflammatory cytokine cocktail. A 93\% reduction in stimulated insulin secretion (over basal) was observed (Fig. 4C).

Pro-inflammatory cytokine-induced changes in ACC AMPK, AMPK-P protein expression and triacylglycerol levels

Fatty acid synthesis is essential for acute and chronic stimulation of insulin secretion (see Newsholme et al. 2007 for review). Fatty acid synthesis is regulated by the enzyme ACC which itself is covalently modified by phosphorylation by the AMP-regulated kinase (AMPK). Phosphorylation of ACC by AMPK will reduce activity. No change in the 
A

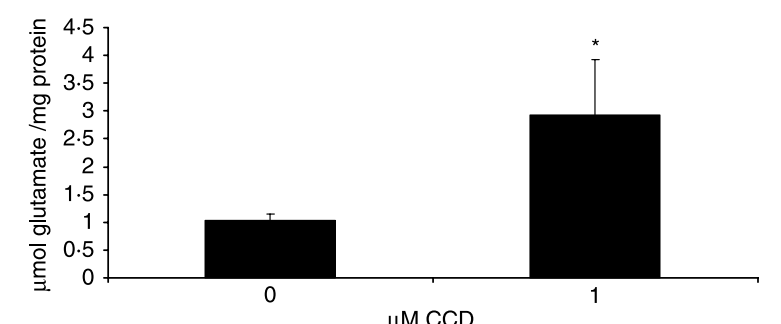

B

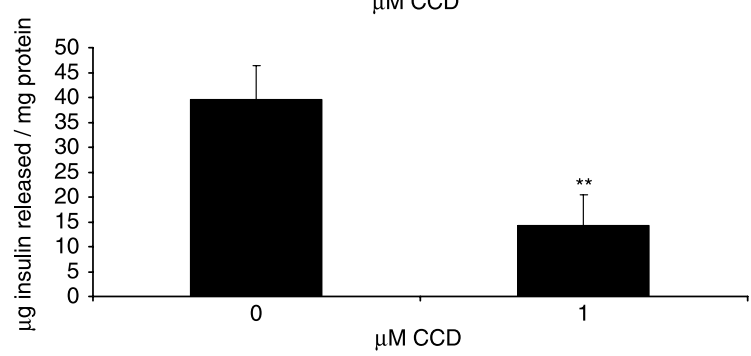

Figure 6 The effect of cytochalasin D on chronic glutamate release from BRIN BD11 cells. Glutamate production (A) and chronic insulin secretion (B) after 24-h treatment of BRIN BD11 cells in RPMI-1640 media supplemented with 10\% (v/v) FCS and $2 \mathrm{mmol} / \mathrm{l}$ glutamine in the absence or presence of $1 \mathrm{mM}$ cytochalasin $\mathrm{D}$. Results are expressed as mean \pm s.D. ${ }^{*} P<0 \cdot 05,{ }^{* *} P<0 \cdot 01$.

expression of the key fatty acid synthesis enzyme ACC was observed after 24-h incubation in the presence of the proinflammatory cytokine cocktail, $P=0.63$ (Fig. 5A).

ACC activity is negatively regulated by phosphorylation by the key signal-transducing kinase, AMPK. A slight decrease in AMPK levels was observed after 24-h exposure to the proinflammatory cytokine cocktail, but this was not significant. Results were normalized and expression of AMPK was reduced from an arbitrary value of 1 to $0.73 \pm 0.32$ units, $P=0 \cdot 23$ (Fig. 5B).

However, a significant increase in phosphorylated AMPK (therefore activated AMPK) levels was observed after 24-h treatment with the cytokine cocktail. Results were normalized and expression of AMPK-P increased from $1 \pm$ 0.59 to $1 \cdot 75 \pm 0.45$ units, $P=0.03$ (Fig. 5C), which may indicate higher levels of phosphorylated ACC, resulting in inhibition of fatty acid synthesis and promotion of FA oxidation.

In support of the latter finding, intracellular triacylglycerol levels were reduced from $0.12 \pm 0.02$ to $0.06 \pm 0.04 \mathrm{mg}$ triglyceride per $\mathrm{mg}$ of protein after $24-\mathrm{h}$ incubation in the presence of cytokines, a reduction of $49 \%, P<0 \cdot 01$ (Fig. 5D). Triacylglycerol synthesis is thought to be cytoprotective in the context of lipotoxicity, but hydrolysis may contribute to stimulation of insulin secretion under appropriate conditions (see Newsholme et al. 2007 for review).

\section{Stimulation of glutamate release by cytochalasin D (CCD)}

There was a significant increase in glutamate export after treatment with the actin microfilament disruptor CCD
$(1 \mu \mathrm{M})$. Glutamate export increased from $1 \cdot 026 \pm 0 \cdot 23$ to $2 \cdot 92 \pm 1.72 \mu \mathrm{mol}$ glutamate $/ \mathrm{mg}$ protein $/ 24 \mathrm{~h}, P=0 \cdot 04$, a $185 \%$ increase after treatment with $1 \mu \mathrm{M}$ CCD (Fig. 6A). There was a significant reduction in chronic insulin secretion after $24-\mathrm{h}$ treatment with $1 \mu \mathrm{M}$ CCD. Insulin secretion was reduced from $39 \cdot 64 \pm 6 \cdot 85$ to $14 \cdot 17 \pm$ $6.33 \mu \mathrm{g}$ insulin $/ \mathrm{mg}$ protein $/ 24 \mathrm{~h}$ treatment in the presence of $1 \mu \mathrm{M}$ CCD, a $64 \%$ reduction in chronic insulin secretion $P<0.001$ (Fig. 6B).

\section{Discussion}

Previous studies have reported that exposure of rat or mouse pancreatic islets to relatively high concentrations of the proinflammatory cytokines IL- $1 \beta$ or TNF- $\alpha$ or a mixture of IL-1 $\beta$, TNF- $\alpha$ and IFN- $\gamma$ resulted in decreased glucose oxidation, decreased activity of glycolytic enzymes and inhibition of insulin secretion (Eizirik et al. 1988, Park et al. 1999, Wallstrom et al. 2003). However, relatively high concentrations of cytokines were previously used (for example, $25 \mathrm{U} / \mathrm{ml} \mathrm{IL}-1 \beta 1000 \mathrm{U} / \mathrm{ml}$ TNF- $\alpha$ and $1000 \mathrm{U} / \mathrm{ml}$ IFN- $\gamma$, Wallstrom et al. 2003), which resulted in rapid stimulation of apoptosis. The study described here employed considerably lower concentrations of proinflammatory cytokines (80-fold, 32-fold and 64-fold for IL- $1 \beta$, TNF- $\alpha$ and IFN- $\gamma$ respectively, IL-1 $\beta \quad 0 \cdot 3125 \mathrm{U} / \mathrm{ml}$, $\mathrm{TNF} \alpha 31 \cdot 25 \mathrm{U} / \mathrm{ml}, \mathrm{IFN} \gamma 15 \cdot 625 \mathrm{U} / \mathrm{ml}$ ) and found enhanced glucose, alanine and triacylglycerol utilization together with concomitant increases in lactate, glutamate and GSH production. The effect of low concentrations of pro-inflammatory cytokines (equivalent to those used in this study) in primary islets has not been addressed. With respect to enzyme activity measurement, we found that maximal LDH activity was not altered after incubation in the presence of pro-inflammatory cytokines. However, both chronic and acute levels of insulin secretion were substantially reduced in agreement with previous reports using higher concentrations of cytokines (Cunningham \& Green 1994, Cunningham et al. 2005). At the cytokine concentrations used in this study, no change was observed in LDH release, MTT reduction or DNA fragmentation after $24 \mathrm{~h}$ thus indicating cellular integrity was maintained under these conditions. Thus, a major question concerns the role of increased fuel utilization in $\beta$ cells exposed to sub-lethal concentrations of pro-inflammatory cytokines. The additional glucose consumed appeared to be mainly converted to lactate, thus suggesting a shift to anaerobic glycolysis and a shift away from glucose-dependent stimulation-secretion coupling. Partial similarity thus exists with in vivo studies demonstrating partial pancreatectomy-induced hyperglycaemia resulted in up-regulation of rat islet cell LDH and monocarboxylate (lactate) transporter gene expression (Laybutt et al. 2002) and thus desensitization to glucose. Cytokines have been shown to increase NO production, NADPH oxidase expression and ROS production ((Eizirik \& Darville 2001, Cunningham et al. 2005, Morgan et al. 2007). The NADPH oxidase complex uses molecular oxygen and NADPH (as a source of reducing 
equivalents) to generate $\mathrm{O}_{2}^{-}$. The source of NADPH is critically important to the $\beta$ cell, which has a relatively low pentose phosphate pathway activity (Papaccio et al. 2005). Interestingly, the $\beta$ cell also contains malic enzyme $\left(\mathrm{NADP}^{+}\right.$- dependent malate dehydrogenase), capable of converting malate to pyruvate with the concomitant production of NADPH from $\mathrm{NADP}^{+}$(MacDonald 1995). The function of NADPH in the $\beta$ cell, although positively correlated with insulin secretion, has never been fully clarified but it may contribute to anti-oxidant mechanisms including the GSH reductase/GSH peroxidase system. We would suggest that NADPH may additionally contribute to ROS generation via its role as substrate in the NADPH-oxidase-catalysed reduction of molecular oxygen. While the full role of ROS in the $\beta$ cell is uncertain, it may influence redox-sensitive enzymes, signal transduction components or transcription factors, which determine insulin

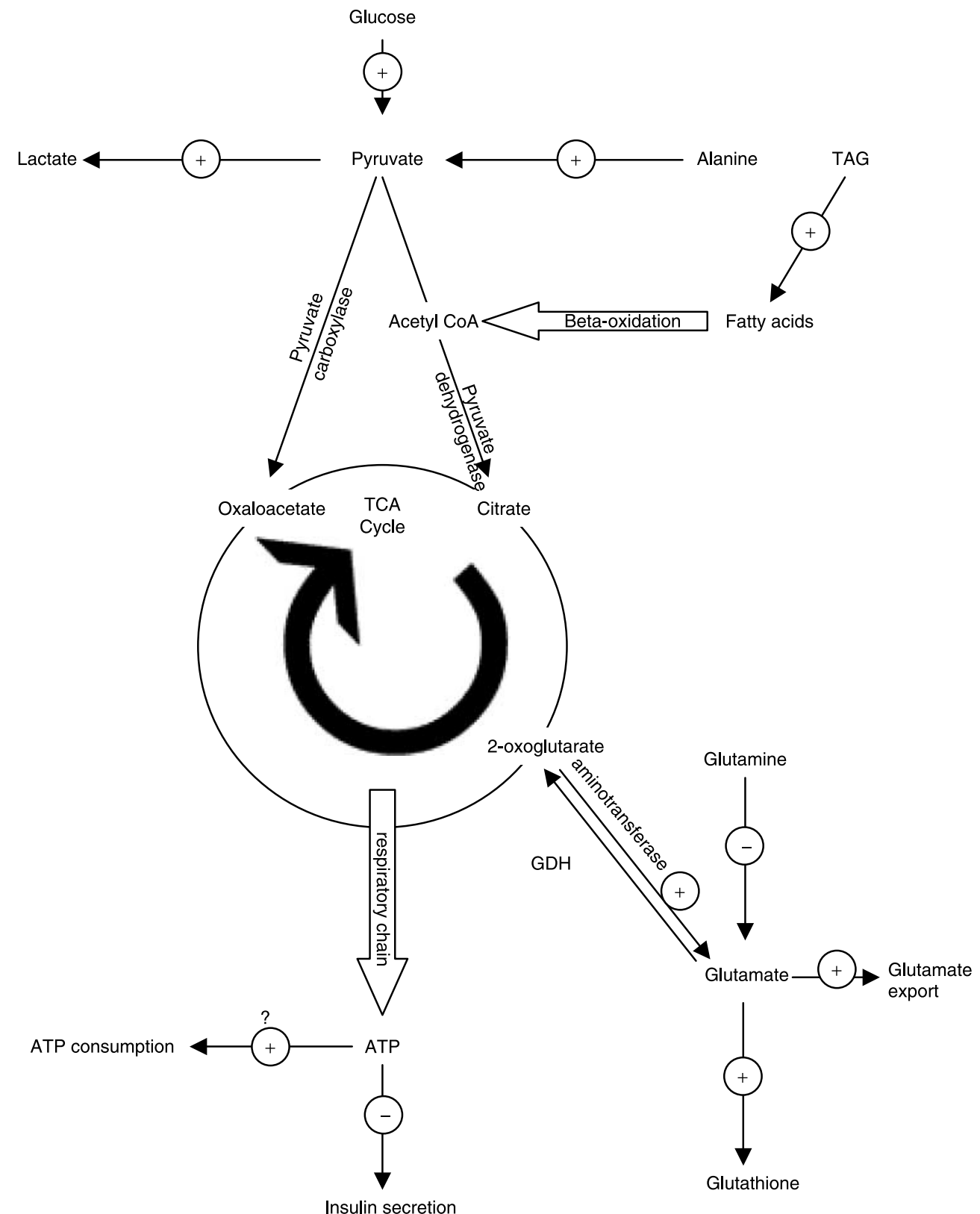

Figure 7 Glucose and amino acid metabolism in cytokine challenged clonal pancreatic $\beta$-cells. Metabolic scheme outlining the increase $(+)$ or decrease $(-)$ in utilization or production of various metabolites in the $\beta$-cell line BRIN BD11 in response to exposure to a sub-lethal concentration of IL-1 $\beta$, TNF- $\alpha$ and IFN- $\gamma$. 
gene transcription or insulin secretion or both. At the low concentration of pro-inflammatory cytokines used in the present study, we did not find a change in expression of the NADPH oxidase subunit $47^{\text {phox }}$ (results not shown). However, under adverse conditions such as sustained exposure to higher concentrations of pro-inflammatory cytokines, the resulting up-regulation and activity of NADPH oxidase may result in excessive ROS initially causing oxidative stress, increased glucose consumption and lactate production but reduced ATP production. However, enhanced ATP consumption resultant from initiation of cell defence mechanisms including activation of ion pumps and transporters will result in a critical fall in ATP levels, insulin secretion and finally apoptosis (Brownlee 2003). That the pro-inflammatory cytokine cocktail decreased $\beta$-cell triacylglycerol level was unexpected, indicating a shift towards fatty acid oxidation or export (Martins et al. 2004). One possibility that might explain the functional impact of TAG hydrolysis in $\beta$ cells is enhanced TAG/FA cycling stimulated by pro-inflammatory cytokine exposure. This can be expected to consume considerable amounts of glucose (as a supplier of glycerol 3-phosphate for esterification) and ATP. The diversion of ATP to TAG/FA cycling and release of potentially high intracellular concentrations of NEFA may negatively impact on $\beta$-cell function and viability (Nolan et al. 2006). The observed increase in phosphorylated AMPK would be expected to enhance ACC phosphorylation and inhibition, correlating well with the cytokine-induced shift towards fatty acid oxidation. The loss of fatty acid synthesis and associated lipid signalling molecule generation via this pathway (Haber et al. 2006, Newsholme et al. 2007) could also contribute to the observed decrease in insulin secretion.

Chronic glutamate release from the $\beta$ cell has been reported (Corless et al. 2006) and suggested to play a role in autocrine/ paracrine inhibition of insulin secretion via activation of metabotropic or ionotropic glutamate receptors described in pancreatic $\beta$ cells and islets (Molnar et al. 1995). The present results demonstrate that pro-inflammatory cytokines increase glutamate release, which might be relevant in the observed inhibition of secretion via glutamate receptor activation. Furthermore, cytochalasin D, an actin microfilament disruptor (Head et al. 2006) enhanced glutamate release from BRINBD11 cells. Since microfilaments play an important role in the movement of insulin granules to the plasma membrane, glutamate may be important for vesicle transport towards exocytotic sites. Disruption of granule movement and fusion might also decrease the requirement for glutamate which was subsequently exported. Interestingly, pro-inflammatory cytokines might also enhance glutamate formation from precursors such as glucose (Brennan et al. 2003, Broca et al. 2003) or alanine (Dixon et al. 2003). This might explain the observed inhibition of glutamine utilization by cytokines.

From the above considerations, pro-inflammatory cytokines appear to shift $\beta$-cell metabolism away from stimulussecretion coupling and towards a catabolic state related to cell defence (see Fig. 7). The endoplasmic reticulum is essential for normal protein synthesis and folding and is crucial for cellular integrity and responses to stress. Cytokines provoke alterations in normal ER function and environment leading to accumulation of unfolded proteins and activation of a specific ER stress response, also known as the unfolded protein response (Cardozo et al. 2005). Three ER signal transduction pathways appear to be important for this stress response. Subsequent downstream events associated with ER-directed transcriptional activation and protein synthesis will place a considerable energy burden on the $\beta$ cell.

In contrast to the reduction in glucose transport and metabolism in muscle and adipose tissues, inflammatory cytokines have been reported to stimulate glucose uptake and metabolism in both $\mathrm{T}$ and B lymphocytes (Frauwirth \& Thompson 2004, Doughty et al. 2006). Of course, cytokine stimulation of lymphocyte growth, maturation and proliferation is well defined and is required for an appropriate immune response. We conclude that enhanced glucose metabolism in response to non-lethal concentrations of cytokines appears to be related to enhanced NADPH production, enhanced metabolic intermediate generation for biosynthetic pathways and enhanced energy requirements. Pro-inflammatory cytokines do not appear to stimulate $\beta$-cell proliferation in vitro or in vivo. However, enhanced metabolic intermediate generation may be required for $\beta$-cell protection and survival. The elevation in GSH levels in $\beta$ cells observed in this study would be consistent with activation in cellular protective mechanisms. Further studies are required to explore these possibilities and ultimately their application to primary human $\beta$ cells.

\section{Acknowledgements}

We thank the European Union Coordination Action TONECA, Health Research Board of Ireland and UCD School of Biomolecular and Biomedical Science for support of this work.

\section{Funding}

This work was supported by the European Union Coordination Action TONECA, The Health Research Board of Ireland and UCD Dublin. There is no conflict of interest in relation to any of the authors of this paper and publication in the Journal of Endocrinology.

\section{References}

Baker MA, Cerniglia GJ \& Zaman A 1990 Microtiter plate assay for the measurement of gluthione and glutathione disul in large numbers of biological samples. Annals of Biochemistry $190360-365$.

Brennan L, Shine A, Hewage C, Malthouse JPG, Brindle K, McClenaghan N, Flatt PR \& Newsholme P 2002 A NMR based demonstration of substantial oxidative L-alanine metabolism and L-alanine enhanced glucose metabolism in a clonal pancreatic $\beta$-cell line - metabolism of $\mathrm{L}$-alanine is important to the regulation of insulin secretion. Diabetes $\mathbf{5 1} 1714-1721$. 
Brennan L, Corless M, Hewage C, Malthouse JPG, McClenaghan NH, Flatt $\mathrm{PR} \&$ Newsholme P $2003{ }^{13} \mathrm{C}$ NMR analysis reveals a link between L-glutamine metabolism, D-glucose metabolism and gamma-glutamyl cycle activity in a clonal pancreatic beta-cell line. Diabetologia 46 1512-1521.

Broca C, Brennan L, Petit P, Newsholme P \& Maechler P 2003 Mitochondriaderived glutamate at the interplay between branched-chain amino acid and glucose-induced insulin secretion. FEBS Letters 545 167-172.

Brownlee M 2003 A radical explanation for glucose induced pancreatic betacell dysfunction. Journal of Clinical Investigation 112 1788-1790.

Cardozo AK, Kruhoffer M, Leeman R, Orntoft T \& Eizirik DL 2001

Identification of novel cytokine-induced genes in pancreatic beta-cells by high-density oligonucleotide arrays. Diabetes 50 909-920.

Cardozo AK, Ortis F, Storling J, Feng YM, Rasschaert J, Tonnesen M, Van Eylen F, Mandrup-Poulsen T, Herchuelz A \& Eizirik DL 2005 Cytokines downregulate the sarcoendoplasmic reticulum pump $\mathrm{Ca}^{2+}$ ATPase $2 \mathrm{~b}$ and deplete endoplasmic reticulum $\mathrm{Ca}^{2+}$, leading to induction of endoplasmic reticulum stress in pancreatic beta-cells. Diabetes 54 452-461.

Chapman JC, McClenaghan NH, Cosgrove KE, Hashmi MN, Shepherd R, Giesberts AN, White S, Ammala C, Flatt PR \& Dunne MJ 1999 ATPsensitive potassium channels and efaroxan-induced insulin release in the elctrofusion-derived BRIN-BD11 beta-cell line. Diabetes 48 2349-2357.

Conroy SJ, Green I, Dixon G, Byrne PM, Nolan J, Abdel-Wahab YH, McClenaghan NH, Flatt PR \& Newsholme P 2002 Evidence for a sustained increase in clonal b-cell basal intracellular $\mathrm{Ca}^{2+}$ levels after incubation in the presence of newly diagnosed Type- 1 diabetic patient sera. Journal of Endocrinology 173 53-62.

Corless M, Kiely A, McClenaghan NH, Flatt PR \& Newsholme P 2006 Glutamine regulates expression of key transcription factor, signal transduction, metabolic gene and protein expression in a clonal pancreatic beta cell line. Journal of Endocrinology 190 719-727.

Cunningham JM \& Green CI 1994 Cytokines, nitric oxide and insulin secreting cells. Growth Regulation 4 173-180.

Cunningham G, McClenaghan NH, Flatt PR \& Newsholme P 2005 L-alanine induces changes in metabolic and signal transduction gene expression in a clonal pancreatic beta cell line and protects from pro-inflammatory cytokine induced apoptosis. Clinical Science 109 447-455.

Curi R, Lagranha CJ, Doi SQ, Sellitti F, Procopio J, Pithon-Curi TC, Corless M \& Newsholme P 2005 Molecular mechanisms of glutamine Action. Journal of Cell Physiology 204 392-401.

Dixon G, Nolan J, McClenaghan NH, Flatt PR \& Newsholme P 2003 A comparative study of amino acid consumption by rat islet cells and the clonal beta-cell line BRIN-BD11 - the functional significance of $\mathrm{L}$-alanine. Journal of Endocrinology 179 447-454.

Doughty CA, Bleiman BF, Wagner DJ, Dufort FJ, Mataraza JM, Roberts MF \& Chiles TC 2006 Antigen receptor-mediated changes in glucose metabolism in B lymphocytes: role of phosphatidylinositol 3-kinase signaling in the glycolytic control of growth. Blood 107 4458-4465.

Eizirik DL \& Darville MI $2001 \beta$-Cell apoptosis and defense mechanisms. Diabetes 1 S64-S69.

Eizirik DL, Strandell E, Bendtzen K \& Sandler S 1988 Functional characteristics of rat pancreatic islets maintained in culture after exposure to human interleukin 1. Diabetes 37 916-919.

Van Eylen F, Horta OD, Barez A, Kamagate A, Flatt PR, Macianskiene R, Mubagwa K \& Herchuelz A 2002 Overexpression of the $\mathrm{Na} / \mathrm{Ca}$ exchanger shapes stimulus-induced cytosolic $\mathrm{Ca}^{2+}$ oscillations in insulin producing BRIN BD11 cells. Diabetes 51 366-375.

Frauwirth KA \& Thompson CB 2004 Regulation of T lymphocyte metabolism. Journal of Immunology 172 4661-4665.

Haber EP, Procópio J, Carvalho CRO, Carpinelli AR, Newsholme P \& Curi R 2006 New insights into fatty acid modulation of pancreatic beta cell function. International Reviews of Cytology 248 1-41.

Head BP, Patel HH, Roth DM, Murray F, Swaney JS, Niesman IR, Farquhar MG \& Insel PA 2006 Microtubules and actin microfilaments regulate lipid $\mathrm{raft} /$ caveolae localization of adenylyl cyclase signalling components.

Journal of Biological Chemistry 281 26391-26399.
Hoorens A, Van de CM, Kloppel G \& Pipeleers D 1996 Glucose promotes survival of rat pancreatic beta cells by activating synthesis of proteins which suppress a constitutive apoptotic program. Journal of Clinical Investigation 98 1568-1574.

Kamencic H, Lyon A, Paterson PG \& Juurlink BH 2000 Monochlorobimane fluorometric method to measure tissue glutathione. Analytical Biochemistry $28635-37$.

Kutlu B, Cardozo AK, Darville MI, Kruhoffer M, Magnusson N, Orntoft T \& Eizirik DL 2003 Discovery of gene networks regulating cytokine-induced dysfunction and apoptosis in insulin-producing INS-1 cells. Diabetes $\mathbf{5 2}$ 2701-2719.

Laybutt DR, Sharma A, Sgroi DC, Gaudet J, Bonner-Weir S \& Weir GC 2002 Genetic regulation of metabolic pathways in b-cells disrupted by hyperglycemia. Journal of Biological Chemistry 277 10912-10921.

Liu D, Pavlovic D, Chen MC, Flodstrom M, Sandler S \& Eizirik DL 2000 Cytokines induce apoptosis in $\beta$-cells isolated from mice lacking the inducible isoform of nitric oxide synthase (iNOS). Diabetes 49 1116-1122.

MacDonald MJ 1995 Feasibility of a mitochondrial pyruvate malate shuttle in pancreatic islets. Further implication of cytosolic NADPH in insulin secretion. Journal of Biological Chemistry 270 20051-20058.

Maechler P 2002 Mitochondria as the conductor of metabolic signals for insulin exocytosis in pancreatic beta-cells. Cellular and Molecular Life Sciences 59 1803-1818.

Maechler P \& Wollheim CB 1999 Mitochondrial glutamate acts as a messenger in glucose-induced insulin exocytosis. Nature 402 595-596.

Martins EF, Miyasaka CK, Newsholme P, Curi R \& Carpinelli AR 2004 Changes of fatty acid composition in incubated rat pancreatic islets. Diabetes and Metabolism 30 21-27.

McClenaghan NH 2007 Functional insights for understanding and therapy of diabetes. Physiological regulation of the pancreatic beta-cell. Experimental Physiology 92 481-496.

McClenaghan NH \& Flatt PR 1999 Engineering cultured insulin-secreting pancreatic $\beta$-cell lines. Journal of Molecular Medicine 77 235-243.

McClenaghan NH, Barnett CR, Ah-Sing E, Abdel-Wahab YHA, O'Harte FPM, Yoon T-W, Swanston-Flatt SK \& Flatt PR 1996a Characterization of a novel glucose-responsive insulin-secreting cell line, BRIN-DB11, produced by electrofusion. Diabetes 45 1132-1140.

McClenaghan NH, Barnett CR, O'Harte FPM \& Flatt PR $1996 b$ Mechanisms of amino acid-induced insulin secretion from the glucoseresponsive BRIN-BD11 pancreatic $\beta$-cell line. Journal of Endocrinology 15 349-357.

Molnar E, Varadi A, McIlhinney RAJ \& Ashcroft SJH 1995 Identification of functional ionotropic glutamate receptor proteins in pancreatic beta cells and in islets of Langerhans. FEBS Letters 371 253-257.

Morgan D, Oliveira-Emilio HR, Keane D, Hirata AE, Santos da Rocha M, Bordin S, Curi R, Newsholme P \& Carpinelli AR 2007 Glucose, palmitate and pro-inflammatory cytokines modulate expression and activity of a phagocyte-like NADPH oxidase in rat pancreatic islets and a clonal $\beta$-cell line. Diabetologia 50 359-369.

Newsholme P, Procopio J, Ramos Lima MM, Pithon-Curi TC \& Curi R 2003 Glutamine and glutamate - their central role in cell metabolism and function. Cell Biochemistry and Function 21 1-9.

Newsholme P, Keane D, Welters H \& Morgan N 2007 Life and death decisions for the pancreatic beta cell - the role of fatty acids. Clinical Science $11227-42$.

Nolan CJ, Madiraju MS, Delghingaro-Augusto V, Peyot ML \& Prentki M 2006 Fatty acid signaling in the beta-cell and insulin secretion. Diabetes $\mathbf{5 5}$ S16-S23.

Oliveira HR, Verlengia R, Carvalho CR, Britto LR, Curi R \& Carpinelli AR 2003 Pancreatic $\beta$-cells express phagocyte-like NAD(P)H oxidase. Diabetes 52 1457-1463.

Papaccio G, Graziano A, Valiante S, D'Aquino R, Travali S \& Nicoletti F 2005 Interleukin (IL)-1beta toxicity to islet beta cells: Efaroxan exerts a complete protection. Journal of Cell Physiology 203 94-102. 
Park C, Kim JR, Shim JK, Kang BS, Park YG, Nam KS, Lee YC \& Kim CH 1999 Inhibitory effects of streptozotocin, TNF $\alpha$ and IL-1 $\beta$ on glucokinase activity in pancreatic islets and gene expression of GLUT2 and glucokinase. Archives of Biochemistry and Biophysics 362 217-224.

Rabinovitch A, Suarez-Pinzon WL, Strynadka K, Lakey JR \& Rajotte RV 1996 Human pancreatic islet $\beta$-cell destruction by cytokines involves oxygen free radicals and aldehyde production. Journal of Clinical Endocrinology and Metabolism 81 3197-3202.

Tietze F 1969 Enzymic method for quantitative determination of nanogram amounts of total and oxidized glutathione: applications to mammalian blood and other tissues. Annals of Biochemistry 27 502-522.
Wallstrom J, Andersson AK \& Sandler S 2003 Effects of IL-15 on suppression of rat pancreatic islets in vitro induced by pro-inflammatory cytokines. Immunology Letters 88 141-145.

Wollheim CB 2000 Beta-cell mitochondria in the regulation of insulin secretion: a new culprit in type II diabetes. Diabetologia 43 265-277.

Received in final form 6 July 2007

Accepted 19 July 2007

Made available online as an Accepted Preprint 19 July 2007 